Article

\title{
Tropical Range Extension for the Temperate, Endemic South-Eastern Australian Nudibranch Goniobranchus splendidus (Angas, 1864)
}

\author{
Nerida G. Wilson ${ }^{1,2, *}$, Anne E. Winters ${ }^{3}$ and Karen L. Cheney ${ }^{3}$ \\ 1 Western Australian Museum, 49 Kew Street, Welshpool WA 6106, Australia \\ 2 School of Animal Biology, University of Western Australia, Crawley 6009 WA, Australia \\ 3 School of Biological Sciences, The University of Queensland, St Lucia QLD 4072, Australia; \\ e.anne06@gmail.com (A.E.W.); k.cheney@uq.edu.au (K.L.C.) \\ * Correspondence: nerida.wilson@museum.wa.gov.au; Tel.: +61-08-9212-3844 \\ Academic Editor: Michael Wink \\ Received: 25 April 2016; Accepted: 15 July 2016; Published: 22 July 2016
}

\begin{abstract}
In contrast to many tropical animals expanding southwards on the Australian coast concomitant with climate change, here we report a temperate endemic newly found in the tropics. Chromodorid nudibranchs are bright, colourful animals that rarely go unnoticed by divers and underwater photographers. The discovery of a new population, with divergent colouration is therefore significant. DNA sequencing confirms that despite departures from the known phenotypic variation, the specimen represents northern Goniobranchus splendidus and not an unknown close relative. Goniobranchus tinctorius represents the sister taxa to G. splendidus. With regard to secondary defences, the oxygenated terpenes found previously in this specimen are partially unique but also overlap with other G. splendidus from southern Queensland (QLD) and New South Wales (NSW). The tropical specimen from Mackay contains extracapsular yolk like other G. splendidus. This previously unknown tropical population may contribute selectively advantageous genes to cold-water species threatened by climate change. Competitive exclusion may explain why G. splendidus does not strongly overlap with its widespread sister taxon.
\end{abstract}

Keywords: Chromodorididae; phenotypic variation; secondary metabolites

\section{Introduction}

Goniobranchus splendidus (Angas, 1864) is a well-known, commonly sighted nudibranch in the temperate to subtropical waters of New South Wales (NSW) and southern Queensland (QLD). Its bright pattern and large size results in it being easily spotted, by divers and presumably by potential predators (Figure 1A). Rudman [1,2] proposed this species forms part of a mimicry ring in the region, where red spots act as a signal, warning potential predators of distasteful or toxic prey. The spongiane diterpenoid metabolites derived from G. splendidus have been shown to have cytotoxic effects [3], and in general, these compounds are known to have antifeedant, anti-infective and anti-inflammatory properties, e.g., [4].

The species was originally described from Sydney Harbour, where it remains easily found. In a redescription of the species, Rudman [1] mentioned two photographic records from Fairfax, which he presumed referred to Fairfax Island, Capricorn and Bunker group, Southern Great Barrier Reef (GBR). Because this was quite far from the known distribution, he initially refrained from accepting these records until better evidence was available. Subsequently, a long-term survey of the nudibranchs of Heron Island (Capricorn and Bunker group, GBR), [5] reported three additional records for this area. The first was a photograph, year unrecorded, and the second was a photograph from 1968. However, 
the third record was a specimen, collected and deposited in Museum Victoria (MV F80627). Still, the occurrence of G. splendidus in the tropics was not widely accepted, and presumably this was reinforced by the lack of any genetic data to support the hypothesis.

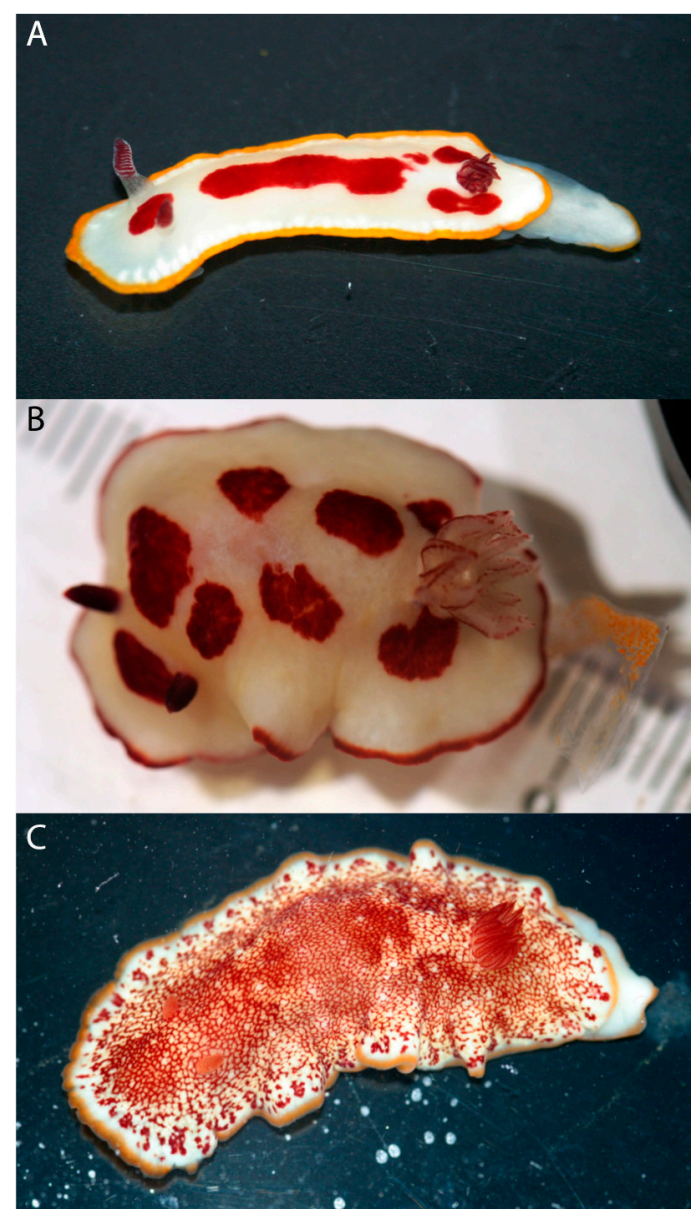

Figure 1. Images of Goniobranchus species under study. (A) G. splendidus from Mooloolaba, Queensland (QLD); (B) tropical specimen of G. cf. splendidus collected from near Mackay, QLD; (C) G. tinctorius from Stradbroke Island.

The variation in pattern is reasonably well-known; spots may vary in shape and size, be completely absent, or coalesce into a single patch [1,6]. Similarly, the colour of these shapes can vary from almost black, to a deep maroon, and to the more commonly seen blood red [7]. Consistent colour and pattern characteristics of G. splendidus include a white background colour, with a gold band at the mantle edge, white/translucent gills edged in red and red rhinophore clubs with white edging [1]. Changes to the dorsal colour and pattern over the geographic range are thought to occur because of mimicry and prey selection [2]. In the south part of its range, G. splendidus typically shows a smaller, evenly spotted pattern, and in northern NSW, the spots become larger and fewer, and may coalesce (Figure 1A). Interestingly, the northernmost specimens known (in the southern GBR) revert to the smaller, evenly spotted phenotype [5].

Here we report a range extension for G. splendidus into the tropics, and with a phenotype not yet reported for this species. We test its identity with molecular data, discuss the implications for identification, and compare the metabolic profiles of specimens throughout the geographic range. 


\section{Materials and Methods}

A red-spotted chromodorid nudibranch was collected off Middle Percy Island, Mackay (Central Queensland) region, $21^{\circ} 39^{\prime} \mathrm{S}, 150^{\circ} 14^{\prime} \mathrm{E}$, in October 2014 (Figure 1B). We refer to it herein as Goniobranchus cf. splendidus. It did not phenotypically match any known nudibranch species from the area. Therefore, we employed a molecular phylogenetic approach to assist with its identification.

We extracted DNA from a tissue sample using a Qiagen DNeasy blood and tissue kit. We then amplified two mitochondrial genes for which large amounts of comparative data are also available on GenBank. These included part of the Cytochrome Oxidase I gene (COI) and also part of the gene coding for ribosomal DNA (16S rDNA). We used the universal primers LCO/HCO [8] and 16SarL/16SbrH [9]; more detailed cycling conditions are available [10]. Amplicons were outsourced for purification and sequencing to the Australian Genome Research Facility.

Chromatograms were reconciled and edited in Geneious v7.1.4 [11], aligned with MAFFT v7.107 [12], and analysed with the raxml GUI [13] implementing a GTR+G model in RAxML v7.4.2 [14]. COI data were translated and checked for stop codons prior to analysis. Data were partitioned by gene, and branch lengths were estimated jointly. Node support was assessed with 100 bootstrap replicates.

As well as generating data for the newly collected Goniobranchus cf. splendidus, we also generated data for the similarly coloured species G. tinctorius (Rüppell and Leuckart, 1828) (Figure 1C), for which no comparative data was available. We included other closely-related taxa for comparison (Table 1), according to the most comprehensive chromodorid phylogeny to date [15], and the tree was rooted with G. kuniei Pruvot-Fol, 1930, a species from the sister clade to the one containing G. splendidus.

Table 1. Species of Goniobranchus included in the phylogenetic analysis.

\begin{tabular}{ccccc}
\hline Species & Voucher & Locality & COI & 16 S \\
\hline G. albopustulosus & CASIZ 142953 & Maui, Hawaii & JQ 727828 & JQ 727701 \\
G. daphne & UQ collection & Gold Coast Seaway, QLD & KJ 001297 & KJ 018921 \\
G. epicurea & SAM D 19285 & Tasmania, Australia & EF 535114 & AY 458804 \\
G. heatherae & CASIZ 175546 & Cape Peninsula, South Africa & JQ 727844 & JQ 727720 \\
G. kuniei & SAM D 19261 & Heron Is., GBR, QLD & EF 535112 & AY 458807 \\
G. splendidus & SAM D 19292 & Mooloolaba, QLD & EF 535115 & AY 458815 \\
G. splendidus & CASIZ 146039 & Mooloolaba, QLD & EU 982738 & EU 982789 \\
G. cf. splendidus & UQ 1102 & Mackay, QLD & MH018011 & MH017998 \\
G. tasmaniensis & SAM 19295 & Triabunna, Tasmania & EF 535113 & AY 458817 \\
G. tinctorius & UQ 1097 & Mackay, QLD & MH018010 & MH01797 \\
G. verrieri & CASIZ 158796 & Batangas, Philippines & JQ 727858 & JQ 727740 \\
\hline
\end{tabular}

\section{Results}

The maximum-likelihood analysis showed that G. cf. splendidus from Mackay was indeed conspecific with other G. splendidus (Figure 2) specimens (now referred herein as tropical G. splendidus). It was strongly supported as the sister to other G. splendidus with a very short internode. The average uncorrected COI $p$-distance between the tropical G. splendidus and the Mooloolaba specimens was 0.0168 . This new specimen therefore represents a range extension of approximately $250 \mathrm{~km}$ northwards, into the tropical, Central Great Barrier Reef region (Figure 3). The most closely related species to G. splendidus was G. tinctorius (Figure 2, BS 99). Comparatively, the $p$-distance between the two Mooloolaba G. splendidus and G. tinctorius was 0.0683 .

Phenotypically, the tropical G. splendidus looked similar to temperate G. splendidus, but lacked the characteristic gold mantle rim and white edging to the red rhinophore clubs. However, it displayed a distinct red mantle rim, unknown in any other $G$. splendidus. It also showed some superficial similarity to G. tumuliferus (Collingwood, 1881). However, G. tumuliferus always has a gold submarginal mantle rim, although specimens from Singapore have shown an additional red/maroon mantle band [16]. 
Most importantly, the rhinophore and gill colour in G. tumuliferus is always a white-ish colour, matching the background body colour [7]. This is unlike all known G. splendidus.

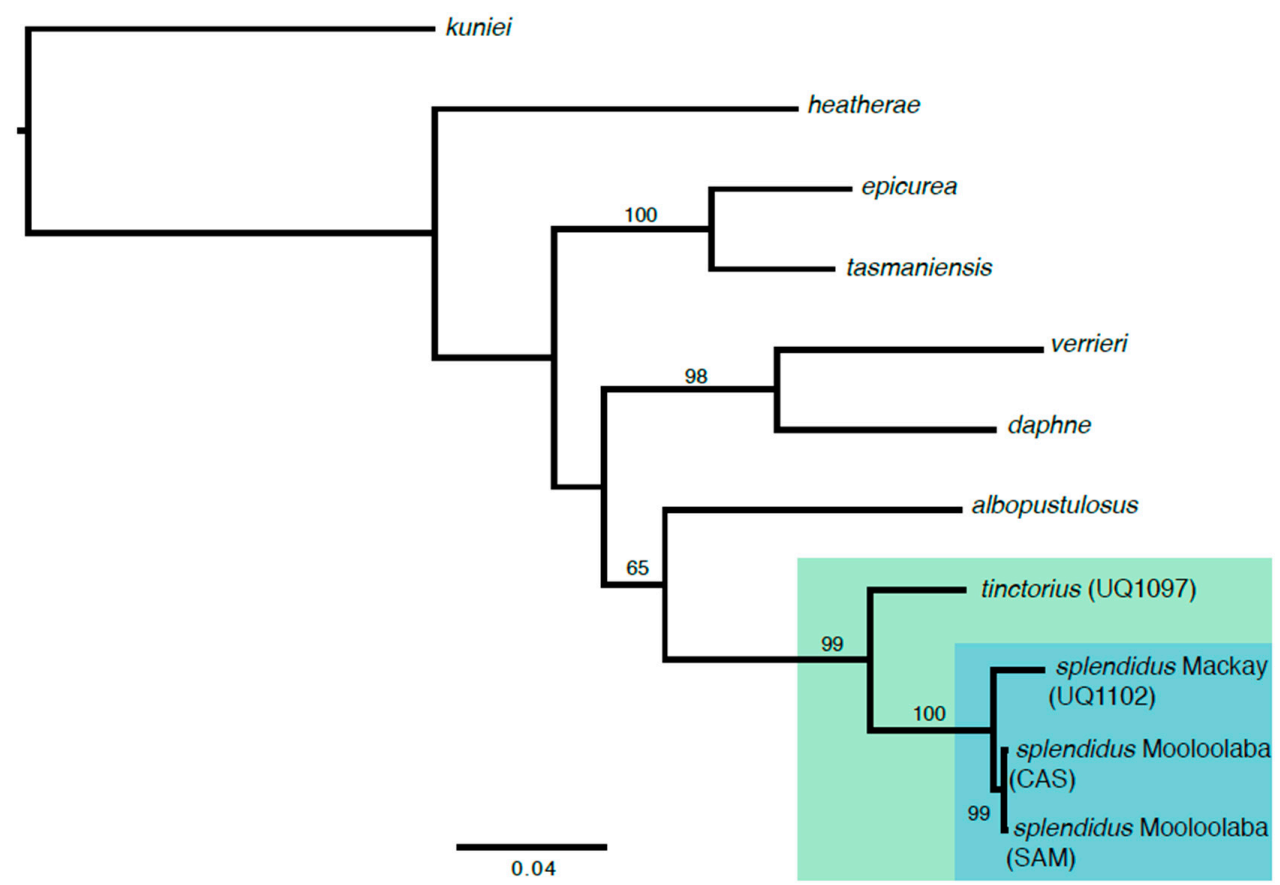

Figure 2. Maximum-likelihood topology for Cytochrome Oxidase I gene (COI) + 16S DNA from selected species of Goniobranchus nudibranchs. Specimens of G. splendidus shown in blue box, and sister species G. tinctorius shown in green box. Bootstrap values less than 60 are not shown.

Photographs of the newly collected tropical G. splendidus show it beginning to lay an egg mass; this is a common response to capture and handling stress [17]. Interestingly, it also shows deposition of extra-capsular yolk reserves (Figure 1B), a phenomenon recorded in some chromodorid genera [18], and subsequently reported from G. splendidus [19].

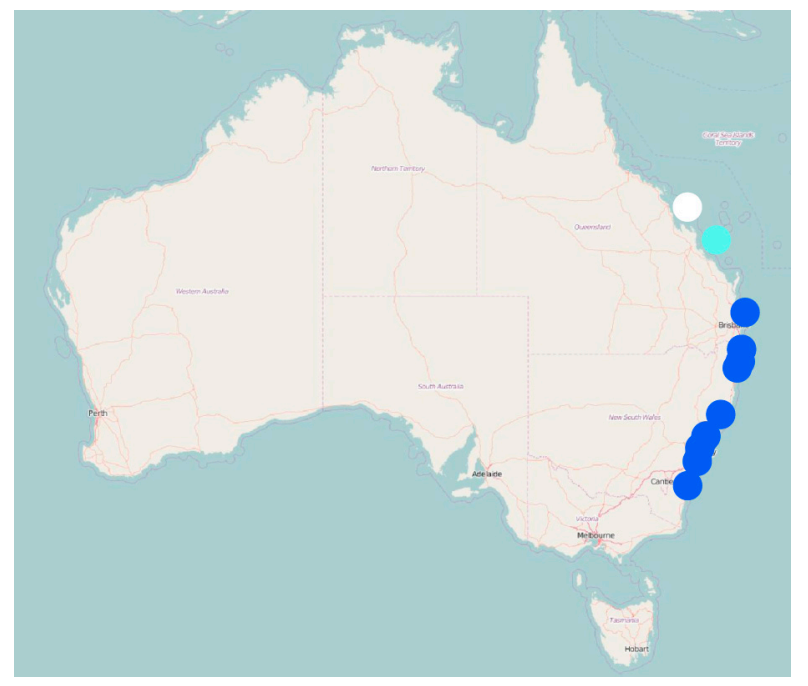

Figure 3. New distribution map for Goniobranchus splendidus. Base map taken from Online Zoological Collections of Australian Museums (OZCAM) [20] blue circles show records from the Australian Museum and Museum Victoria. White circle shows tropical occurrence reported in this study; light blue circle shows poorly known occurrence off the southern Great Barrier Reef (GBR). 
The oxygenated terpenes of G. splendidus from Sydney (NSW), Mooloolaba (southern QLD), Coffs Harbour (NSW) and the new tropical specimen overlap but still differ significantly (Table 2). There were four compounds found across multiple locations (tropical QLD, southern QLD, NSW), although only one of these, aplysulphurin, was present in all localities (Table 1). The Mackay specimen had at least 10 unique compounds recovered from it, although specimens from Mooloolaba show a similarly high number of unique compounds (Table 2).

Table 2. Comparison of G. splendidus oxygenated terpenes from a range of geographic localities [3,19]. Specimens are referred to by voucher number if separation of individuals was possible. Compounds in upper section of table are recovered from multiple localities, compounds in middle section are found in multiple individuals. Compounds in the lower section are unique to one individual.

\begin{tabular}{|c|c|c|c|c|}
\hline Compound & $\begin{array}{c}\text { G. splendidus } \\
\text { Mackay QLD } \\
(n=1)[21]\end{array}$ & $\begin{array}{c}\text { G. splendidus } \\
\text { Mooloolaba } \\
\text { QLD }(n=3)[21]\end{array}$ & $\begin{array}{c}\text { G. splendidus } \\
\text { Mooloolaba } \\
\text { QLD }(n=2)[3]\end{array}$ & $\begin{array}{c}\text { G. splendidus } \\
\text { Coffs Harbour, } \\
\text { NSW }(n=1)\end{array}$ \\
\hline tetrahydroaplysulphurin-1 & & $931,927,928$ & & 1105 \\
\hline $7 \alpha$-acetoxyspongian-16-one & & & yes & 1105 \\
\hline aplyroseol-2 & 1102 & & yes & \\
\hline membranolide & & 931,927 & & \\
\hline spongian-16-one & & 928 & yes & \\
\hline tetrahydroaplysulphurin- 4 & 1102 & & & \\
\hline dendrillolide $\mathrm{A}$ & 1102 & & & \\
\hline macfarlandin C, D, E & 1102 & & & \\
\hline norrisolide & 1102 & & & \\
\hline 15,16-Deacetoxy-15-hydroxy-9,11-dihydrogracilin A & & 931 & & \\
\hline 16-Deacetoxy-9,11-dihydrogracilin A & & 927 & & \\
\hline tyrinnal, tyrinnal B & & 928 & & \\
\hline aplytandiene- 3 & & & yes & \\
\hline gracilin $\mathrm{A}, \mathrm{M}, \mathrm{N}, \mathrm{O}, \mathrm{Q}, \mathrm{C}, \mathrm{G}$ & & & yes & \\
\hline $6 \mathrm{Z}$ isomers of gracilin $\mathrm{B}, \mathrm{C}$ & & & yes & \\
\hline splendidalactone- 1 & & & & 1105 \\
\hline aplyviolene & & & & 1105 \\
\hline
\end{tabular}

\section{Systematics}

Order NUDIBRANCHIA Cuvier, 1817; Suborder EUCTENIDIACEA Tardy, 1970; Infraorder DORIDOIDEA Rafinesque, 1815; Family CHROMODORIDIDAE Bergh, 1891; Genus Goniobranchus Pease, 1866; Goniobranchus splendidus (Angas, 1864); (Figure 1A,B, Figures 2 and 3).

Goniodoris splendida: Angas, 1864, pp. 55-56, pl. V, Figure 2 [22]; Burn, 1965, pp. 88 [23].

Chromodoris splendida: Abraham, 1877, pp. 218 [24]; Bergh, 1892, pp. 1109 [25]; Eliot, 1904, pp. 390 [26]; Rudman, 1973 [27]; Thompson, 1972, pp. 406-407, pls 2 and 3, Figure 2 [28]; Rudman, 1983, pp. 107-112, Figures 1A, 2 and 3 [1]; Rudman, 1984, pp. 125, 132-133, Figures 5, 8 and Table 3 [29]; Rudman, 1990, pp. 310 [6]; Rudman, 1991, pp. 11, 16, 17, 19, Figure 2, Tables 1, 2 [2];

Hypselodoris splendida: Basedow and Hedley, 1905, pp. 142 [30];

Glossodoris splendida: Allan, 1947, pp. 443 [31].

Type Material: Unknown.

External Diagnosis: Mantle white, with marginal band of gold or red. Sides of foot and underside of mantle also white. Posterior dorsal foot may show marginal band similar to mantle. Central dorsum usually has red spots (range from orange to nearly black), but these can be absent. Spots can also coalesce into patches. Rhinophore stalk white/translucent and rhinophore clubs are dark red. These usually have white edging to the lamellae, although this is not always obvious. Gills quadrangular, white/translucent with red line running up each corner. Gills are arranged in an arc around the anus, 
with the ends smaller and curving posteriorly. Mantle is broad and extends beyond foot, typically obscuring it.

Distribution: Middle Percy Island, Central GBR, south to Narooma, NSW.

\section{Discussion}

Although records from the southern GBR have been known, these were not a widely known or widely accepted part of the species distribution, perhaps because of the unexpected small-spotted phenotype. The remaining small-spotted populations are only known from the southern part of the range in New South Wales. Because an increasing number of cryptic species are being found in nudibranchs e.g. [10], it is not surprising that a large amount of scepticism remained regarding whether these small spotted GBR specimens indeed represented true G. splendidus. Indeed, this remains untested in a molecular context, as no GBR specimens have been sequenced to date. However, our new record of a confirmed G. splendidus in the GBR (with another atypical phenotype), establishes that this species persists in much warmer water than expected. Other aberrant phenotypes of putative G. splendidus (e.g., unspotted) have also been sequenced and shown to belong to that species [32]. In the course of this study, an additional potential tropical specimen was uncovered at the Australian Museum (AMS C.121533). Although no locality information was noted, an explanation in the remarks field reports "Cairns area' ex Mona Vale Aquariums. Locality dubious, not entered, IL, 4/98". Although this may represent a situation where an aquarium supplier may have mistakenly given the incorrect locality data, in light of this study, such records could be reinvestigated. Tropical populations are of interest because they may contribute selectively advantageous genes to cold-water species threatened by climate change.

The variation in chemical compounds recovered in G. splendidus from different localities most likely reflects differences in available sponge prey. Because $G$. splendidus sequesters the compounds or their precursors from its prey [33,34], differences among ingested prey are likely to result in different metabolic profiles. This explains why the chemical profile can vary across different individuals from the same locality e.g., Sydney [19]. The tropical G. splendidus shares several compounds with other temperate localities, and although it also harbours some unique chemicals, other localities show a similarly high level of unique compounds [3].

One possibility is for G. splendidus being absent in most tropical areas may be related to direct competition with G. tinctorius. It must be noted that although G. tinctorius occurs widely in the Indo-Pacific (from Hawaii to the Red Sea), it is remarkably absent in most of NSW, where G. splendidus is most abundant (with the exception of Byron Bay in the north). Vicariance biogeography predicts sister species will be adjacent to each other rather than sympatric [35]. Although there is no reason to suspect a historical vicariant barrier in northern NSW, competitive exclusion principles also predict that ecologically identical species will be unable to co-occur [36,37].

To test this hypothesis further, two important points must be ascertained i) whether the widespread and variable $G$. tinctorius is a single species or a complex of cryptic species and ii) what sponges G. tinctorius feeds on. Rudman [26] carried out a morphological revision of G. tinctorius, and recognised many synonyms, but acknowledged further work was necessary because there are several similar red-spotted species. Since that time, the use of DNA has substantially improved our ability to detect species-level differences, and the group certainly requires further attention. In regard to diet, G. splendidus is known to feed on at least four species of sponges [38], but the diet of G. tinctorius remains unknown.

Acknowledgments: Animals were collected under the following permits: Queensland General Fisheries Permit \#161624 and NSW Industry and Investment Scientific Collection Permit F86/2163-7.0. Ashley Roberts-Thompson is thanked for collecting the intriguing Mackay specimen of G. splendidus, and Kara Layton assisted with sequencing. NGW was supported by the Net Conservation Benefits Fund. AEW was supported by an Endeavour Postgraduate Award from the Australian Government. The project was supported by an Australian Pacific Science Foundation (APSF) grant awarded to KLC. 
Author Contributions: N.G.W. conceived and drafted the paper, and carried out analyses. All authors helped edit the manuscript.

Conflicts of Interest: The authors declare no conflict of interest.

\section{Abbreviations}

The following abbreviations are used in this manuscript:

$\begin{array}{ll}\text { AMS } & \text { Australian Museum, Sydney } \\ \text { CASIZ } & \text { California Academy of Sciences, Invertebrate Zoology } \\ \text { COI } & \text { Cytochrome Oxidase I } \\ \text { GBR } & \text { Great Barrier Reef } \\ \text { MV } & \text { Museum Victoria } \\ \text { NSW } & \text { New South Wales, Australia } \\ \text { QLD } & \text { Queensland Australia } \\ \text { SAM } & \text { South Australian Museum } \\ \text { UQ } & \text { University of Queensland } \\ \text { 16S rDNA } & \text { 16S ribosomal DNA }\end{array}$

\section{References}

1. Rudman, W.B. The Chromodorididae (Opisthobranchia: Mollusca) of the Indo-West Pacific: Chromodoris splendida, C. aspersa and Hypselodoris placida colour groups. Zool. J. Linn. Soc. 1983, 78, 105-173. [CrossRef]

2. Rudman, W.B. Purpose in pattern: The evolution of colour in chromodorid nudibranchs. J. Mollusc. Stud. 1991, 57, 5-21. [CrossRef]

3. Hirayama, Y.; Katavic, P.L.; White, A.M.; Pierens, G.K.; Lambert, L.K.; Winters, A.E.; Kigoshi, H.; Kita, M.; Garson, M.J. New cytotoxic norditerpenes from the Australian nudibranchs Goniobranchus splendidus and Goniobranchus daphne. Aust. J. Chem. 2015, 69, 136-144. [CrossRef]

4. González, M.A. Spongiane diterpenoids. Curr. Bioact. Compd. 2007, 3, 1-36.

5. Marshall, J.G.; Willan, R.C. Nudibranchs of Heron Island, Great Barrier Reef: A survey of the Opisthobranchia (sea slugs) of Heron and Wistari Reefs; Backhuys: Leiden, The Netherlands, 1999.

6. Rudman, W.B. The Chromodorididae (Opisthobranchia: Mollusca) of the Indo-West Pacific: further species of Glossodoris, Thorunna and the Chromodoris aureomarginata colour group. Zool. J. Linn. Soc. 1990, 100, 263-326. [CrossRef]

7. Debelius, H.; Kuiter, R.H. Nudibranchs of the World; Ikan-Unterwasserarchiv: Frankfurt, Germany, 2007.

8. Folmer, O.; Black, M.; Hoeh, W.; Lutz, R.; Vrijenhoek, R. DNA primers for amplification of mitochondrial cytochrome c oxidase subunit I from diverse metazoan invertebrates. Mol. Mar. Biol. Biotech. 1994, 3, 294-299.

9. Palumbi, S; Martin, A; Romano, S; McMillan, W; Stice, L; Grabowski, G. The Simple Fool's Guide to PCR; University of Hawaii: Honolulu, HI, USA, 1991; p. 361.

10. Wilson, N.G.; Maschek, J.A.; Baker, B.J. A species flock driven by predation? Secondary metabolites support diversification of slugs in Antarctica. PLoS ONE 2013, 8, e80277. [CrossRef] [PubMed]

11. Kearse, M; Moir, R; Wilson, A; Stones-Havas, S; Cheung, M; Sturrock, S; Buxton, S; Cooper, A; Markowitz, S; Duran, C; et al. Geneious Basic: An integrated and extendable desktop software platform for the organization and analysis of sequence data. Bioinformatics 2012, 28, 1647-1649. [CrossRef] [PubMed]

12. Katoh, K.; Misawa, K.; Kuma, K.I.; Miyata, T. MAFFT: A novel method for rapid multiple sequence alignment based on fast Fourier transform. Nucl. Acids Res. 2002, 30, 3059-3066. [CrossRef]

13. Silvestro, D.; Michalak, I. raxmlGUI: A graphical front-end for RAxML. Org. Divers. Evol. 2012, 12, $335-337$. [CrossRef]

14. Stamatakis, A. RAxML-VI-HPC: Maximum likelihood-based phylogenetic analyses with thousands of taxa and mixed models. Bioinformatics 2006, 22, 2688-2690. [CrossRef] [PubMed]

15. Johnson, R.F.; Gosliner, T.M. Traditional taxonomic groupings mask evolutionary history: A molecular phylogeny and new classification of the chromodorid nudibranchs. PLoS ONE 2012, 7, e33479. [CrossRef] [PubMed] 
16. Lim, H.P. Chromodoris tumulifera from Singapore. Available online: http://www.seaslugforum.net/find/ 13223 (accessed on 15 July 2016).

17. Hadfield, M.G.; Switzer-Dunlap, M. Opisthobranchs. In The Mollusca; Wilbur, K., Ed.; Academic Press: New York, NY, USA, 1984; pp. 209-350.

18. Wilson, N.G. Egg masses of chromodorid nudibranchs (Mollusca: Gastropoda: Opisthobranchia). Malacologia 2002, 44, 289-306.

19. Atkinson, L.; Atkinson, D. Re: Chromodoris splendida laying eggs. Available online: http://www. seaslugforum.net/find/21334 (accessed on 15 July 2016).

20. OZCAM. Available online: http:/ / ozcam.ala.org.au/ (accessed on 16 March 2016).

21. White, A.M.; Pierens, G.K.; Forster, L.C.; Winters, A.E.; Cheney, K.L.; Garson, M.J. Rearranged diterpenes and norditerpenes from three Australian Goniobranchus mollusks. J. Nat. Prod. 2015, 79, 477-483. [CrossRef] [PubMed]

22. Angas, G.F.; Crosse, J.C.H. Description d'espèces nouvelles appartenant à plusieurs genres de mollusques nudibranches des environs de Port-Jackson (Nouvelle-Galles du Sud): Accompagnée de dessins faits d'après nature. J. Conchyliol. 1864, 12, 43-70.

23. Burn, R. A centennial commentary and zoogeographical remarks on Angas' Sydney nudibranchs (Molluscs, Gastropoda). J. Conchyliol. 1965, 104, 85-93.

24. Abraham, P.S. Revision of the anthobranchiate nudibranchiate Mollusca, with descriptions or notices of forty-one hitherto undescribed species. Proc. Zoo. Soc. Lond. 1877, 1877, 196-269.

25. Bergh, L.S.R. Malacologische Untersuchungen. System der Nudibranchiaten Gasteropoden. In Reisen im Archipel der Philippinen von Dr. Carl Gottfried Semper; Zweiter, T., Ed.; C.W. Kreidel's Verlag: Wiesbaden, Germany, 1892; Wissenschaftliche Resultate Band 2, Theil 3 (Heft 18); pp. 995-1168.

26. Eliot, C.N. On some nudibranchs from East Africa and Zanzibar. Part IV. Proc. Zool. Soc. Lond. 1904, 74, 380-406. [CrossRef]

27. Rudman, W.B. Chromodorid opisthobranch Mollusca from the Indo-West Pacific. Zool. J. Linn. Soc. 1973, 52, 175-199. [CrossRef]

28. Thompson, T.E. Chromodorid nudibranchs from eastern Australia (Gastropoda, Opisthobranchia). J. Zool. 1972, 166, 391-409. [CrossRef]

29. Rudman, W.B. The Chromodorididae (Opisthobranchia: Mollusca) of the Indo-West Pacific: A review of the genera. Zool. J. Linn. Soc. 1984, 81, 115-273. [CrossRef]

30. Basedow, H.; Hedley, C. South Australian nudibranchs, and an enumeration of the known Australian species. Roy. Soc. S. Aust. 1905, 29, 134-160.

31. Allan, J. Nudibranchiata from Clarence River Heads, North Coast, New South Wales. Rec. Aust. Mus. 1947, 21, 433-463. [CrossRef]

32. Winters, A.E.; Wilson, N.G.; White, A.M.; How, M.; Garson, M.J.; Cheney, K.L. Geographic divergence of warning signals in nudibranch mollusc. In preparation.

33. Hambley, T.W.; Poiner, A.; Taylor, W.C. The constituents of marine sponges. V. The isolation from Chelonaplysilla violacea (Dendroceratida) of Aplyviolene and other diterpenes, and the determination of the crystal structure of Aplyviolene. Aust. J. Chem. 1990, 43, 1861-1870. [CrossRef]

34. Poiner, A.; Taylor, W.C. The constituents of marine sponges. IV. The isolation of degraded Spongian diterpenoids from Aplysilla tango (sp. nov.) (Dendroceratida). Aust. J. Chem. 1990, 43, 1713-1727. [CrossRef]

35. Nelson, G.; Platnick, N.I. Systematics and Biogeography; Columbia University Press: New York, NY, USA, 1981; p. 567.

36. Hardin, G. The competitive exclusion principle. Science 1960, 131, 1292-1297. [CrossRef] [PubMed]

37. Bengtsson, J. Interspecific competition increases local extinction rate in a metapopulation system. Nature 1989, 340, 713-715. [CrossRef]

38. Rudman, W.B.; Bergquist, P.R. A review of feeding specificity in the sponge-feeding Chromodorididae (Nudibranchia: Mollusca). Mollus. Res. 2007, 27, 60-88.

(C) 2016 by the authors; licensee MDPI, Basel, Switzerland. This article is an open access article distributed under the terms and conditions of the Creative Commons Attribution (CC-BY) license (http://creativecommons.org/licenses/by/4.0/). 